Marcin Drewek

Uniwersytet Mikołaja Kopernika, Toruń

\title{
Glosa do wyroku Sądu Najwyższego z dnia 12 września 2013 r., IV CSK 44/13
}

DOI: http://dx.doi.org/10.12775/SIT.2015.030

„Wydzierżawiającemu nie przysługuje przewidziane w art. 676 w zw. z art. 694 k.c. prawo żądania przywrócenia stanu poprzedniego przedmiotu dzierżawy jeżeli taka restytucja naruszałaby substancję nieruchomości lub zmieniałaby jej przeznaczenie i charakter nabyte dzięki poczynionym nakładom" 1 .

Glosowane orzeczenie, wśród wielu problemów, dotyka niezwykle ważkiej dla obecnego obrotu prawnego kwestii dotyczącej dopuszczalności ograniczenia- przysługującego wydzierżawiającemu prawa wyboru między zachowaniem nakładów (ulepszeń), a żądaniem przywrócenia przedmiotu dzierżawy do stanu poprzedniego (restytucji).Wskazane zagadnienie wiąże się z coraz częstszym wykorzystywaniem w obrocie gospodarczym umowy dzierżawy (umów do niej podobnych) dla celu zmiany przeznaczenia nieruchomości. Jest to szczególnie widoczne na gruncie umów zawieranych przez jednostki samorządu terytorialnego na potrzeby realizacji regionalnej polityki

${ }^{1}$ Wyrok SN z dnia 12 września 2013 r., IV CSK 44/13, „Rzeczpospolita” (Prawo co dnia), 2013/216/2. 
samorządowej, inwestycji gospodarczych oraz zaspokojenia potrzeb lokalnej społeczności².

Problem ograniczenia przysługującego wydzierżawiającemu prawa wyboru powstał na gruncie następującego stanu faktycznego. Wydzierżawiający (gmina) zawarł z dzierżawcą (przedsiębiorca) umowę dzierżawy nieruchomości. Dzierżawca zobowiązał się do uporządkowania gruntu i wykonania na własny koszt materiałów urbanistycznych dla realizacji miejscowego planu zagospodarowania przestrzennego. Strony zawarły ponadto porozumienie, w którym dzierżawca zobowiązał się do dokonania czynności (uporządkowania, nawiezienia ziemi) dla przygotowania dzierżawionej nieruchomości pod lokalizację wypożyczalni sprzętu wodnego. Dzierżawca dokonał wskazanych czynności za zgodą i wiedzą wydzierżawiającego. W wyniku sporu między stronami wydzierżawiający wypowiedział umowę, a po zakończeniu postępowań sądowych uzyskał posiadanie nieruchomości w wyniku egzekucji. Dzierżawca wystąpił o zapłatę za poczynione ulepszenia. Wydzierżawiający odmówił zapłaty, a następnie zażądał przywrócenia stanu poprzedniego.

Sąd Najwyższy rozważył w glosowanym wyroku kwestię, czy dopuszczalne jest ograniczenie prawa wyboru pomiędzy zatrzymaniem za zapłatą ulepszeń dokonanych przez dzierżawcę na przedmiocie dzierżawy, a żądaniem przywrócenia stanu poprzedniego (art. 676 k.c.).Wskazane prawo wyboru stanowi uprawnienie ( $f a-$ cultas alternativa) przysługujące wydzierżawiającemu ${ }^{3} . Z$ treści wskazanego przepisu wynika dopuszczalność jego ograniczenia z uwagi na wolę stron ${ }^{4}$. Co więcej, art. 676 k.c. stosuje się do umowy dzierżawy odpowiednio, należy wobec tego uwzględniać specyfikę

2 Zob. np. wyrok SA w Szczecinie z dnia 30 stycznia 2014 r., I ACa 602/13, LEX Nr 1454617; wyrok SN z dnia 8 lipca 2010 r., II CSK 85/10, Orzecznictwo Sądu Najwyższego - Zbiór Dodatkowy 2011 Nr 1, poz. 13; por. także P. Machnikowski, Skutki prawne ulepszenia przedmiotu najmu wg art. 676 k.c., w: Zawieranie i wykonywanie umów wybrane zagadnienia, red. E. Gniewek, Prawo CCLXXXIX, Wrocław 2004, s. 210.

${ }^{3}$ Zob. np. G. Kozieł, w: Kodeks cywilny. Komentarz, red. A. Kidyba, Zobowiązania część szczególna, t. III, Warszawa 2010, s. 396; J. Jezioro, w: Kodeks cywilny. Komentarz, red. E. Gniewek, Warszawa 2011, s. 1168.

${ }^{4}$ Zob. np. G. Kozieł, op. cit., s. 395. 
umowy dzierżawy(art. 694 k.c.) $)^{5}$, w szczególności okoliczność, że przedmiot dzierżawy winien zostać zwrócony w stanie, w jakim powinien się znajdować stosownie do przepisów o wykonywaniu dzierżawy (art. 705 k.c.) ${ }^{6} . Z$ wskazanych przepisów wynika więc, że ograniczenia analizowanego prawa wyboru mogą nastąpić w oparciu o dwie okoliczności: po pierwsze wolę stron (umownie), a w jej braku stosownie do przepisów ustawy (ustawowo), przy czym wystarczające jest wystąpienie jednej tych okoliczności.

Można dodać, że w przypadku, gdyby nakłady (ulepszenia)pozostały na przedmiocie dzierżawy ( $\mathrm{z}$ wyboru wydzierżawiającego lub $z$ uwagi na umowne lub ustawowe ograniczenia prawa wyboru), strony powinny dokonać ich rozliczenia ${ }^{7}$. W glosowanym orzeczeniu trafnie wskazano, że zwrotowi podlega wartość nakładów (nie wydatków) powodujących rzeczywisty wzrost wartości lub użyteczności rzeczy (ulepszenia). Sposób rozliczenia może nastąpić na różne sposoby. Brak jakiegokolwiek ekwiwalentu lub uwzględnienia poczynionych nakładów (poza tymi, które obciążają dzierżawcę) nie wydaje się zasadniczo dopuszczalny ${ }^{8}$. Natomiast w przypadku wyboru przywrócenia stanu poprzedniego obowiązek zapłaty zasadniczo nie powstaje ${ }^{9}$. Obowiązek zapłaty może także powstać $z$ innych podstaw prawnych ${ }^{10}$.

${ }^{5}$ Zob. wyrok SN z dnia 8 lipca 2010 r., II CSK 85/10, op. cit.; K. Zaradkiewicz, w: Kodeks cywilny. Komentarz do artykułów 450-1088, red. K. Pietrzykowski, t. II, Warszawa 2011, s. 548; J. Szachułowicz, Dzierżawa gruntów rolnych, „Nowe Prawo” 1989, nr 1, s. 25.

${ }^{6}$ Zob. wyrok SN z dnia 7 kwietnia 2005 r., II CK 565/04, „Gazeta Prawna” 2005/70/22.

7 Por. np. J. Jezioro, op. cit., s. 1168; wyrok SN z dnia 9 listopada 2000 r., II CKN 339/00, LEX Nr 536762.

${ }^{8}$ Zob. np. wyrok SA w Białymstoku z dnia 27 czerwca 2013 r., I ACa 266/13, LEX Nr 1335609.

9 Por. np. wyrok SN z dnia 26 czerwca 2008 r., II CSK 69/08, LEX Nr 548800; wyrok SN z dnia 12 listopada 1982 r., III CRN 269/82, LEX Nr 8484; K. Pietrzykowski, w: Kodeks cywilny. Komentarz do artykułów 450-1088, red. K. Pietrzykowski, t.II, Warszawa 2011, s. 489; K. Zaradkiewicz, op. cit., s. 562; W. Pańko, Dzierżawa gruntów rolnych, Warszawa 1975, s. 90-91.

${ }^{10}$ Zob. np. G. Kozieł, op. cit., s. 396. 
Ograniczenie przysługującego wydzierżawiającemu prawo wyboru może wynikać $z$ woli stron. Strony mogą swobodnie zdecydować o dalszym losie nakładów, w szczególności o ich pozostawieniu (w całości lub części) lub odpowiednio usunięciu i przywróceniu stanu poprzedniego (art. 676 k.c. i 705 k.c.).Jak się wydaje, wola stron w tym zakresie może zostać wyrażona w dowolnej formie, w tym w sposób dorozumiany (art. 60 k.c. i 65 k.c.). Żądanie restytucji przedmiotu dzierżawy zasadniczo nie będzie więc dopuszczalne, jeśli wynika to bezpośrednio lub nawet pośrednio $z$ woli stron. Przy czym wola ta podlega badaniu w zakresie zgodności z prawem (art. $353^{1}$ k.c.). Bezpośrednie wyrażenie woli stron, ograniczające prawo wyboru wydzierżawiającego, miałoby miejsce w przypadku wyraźnego ustanowienia przez nie zakazu żądania restytucji (np. klauzula w treści umowy). Pośrednie wyrażenie woli stron, wskazujące na niedopuszczalność prawa wyboru, może nastąpić przez każde zachowanie (także konkludentne), ujawniające w sposób dostateczny, że ich wolą jest wyłączenie możliwości żądać restytucji (art. 60 k.c.) ${ }^{11}$.

$\mathrm{Na}$ zakaz restytucji mogłaby w szczególności wskazywać wola stron dokonania określonych nakładów (ulepszeń) na przedmiot dzierżawy (np. zwłaszcza dokonanych na stałe lub w celu zmiany jego przeznaczenia). Wola wydzierżawiającego co do ulepszenia przedmiotu dzierżawy mogłaby więc skutkować niedopuszczalnością późniejszego żądania przywrócenia stanu poprzedniego, z racji sprzeczności $z$ wolą stron ${ }^{12}$. Odmienna sytuacja mogłaby mieć miejsce, gdyby nakładów dokonano wyłącznie w interesie dzierżawcy lub jedynie na czas trwania umowy dzierżawy ${ }^{13}$.

${ }^{11}$ Por. wyrok SN z dnia 8 lipca 2010 r., II CSK 85/10, op. cit.; wyrok SN z dnia 14 października 2009 r., V CSK 111/09, Orzecznictwo Sądu Najwyższego - Zbiór Dodatkowy 2010 Nr 4, poz. 101 (zasadniczo dotyczący nakładów w przypadku umowy zlecenia); wyrok SN z dnia 7 kwietnia 2005 r., II CK 565/04, op. cit.; G. Kozieł op. cit., s. 395; P. Machnikowski, op. cit., s. 223-224.

${ }^{12} \mathrm{~W}$ praktyce żądanie restytucji mogłoby prowadzić do prób uchylania się obowiązku zapłaty, co mogło mieć miejsce w stanie faktycznym glosowanego orzeczenia.

${ }^{13}$ Por. Z. Radwański, J. Panowicz-Lipska, Zobowiązania-część szczegółowa, Warszawa 2008, s. 137. 
Pośrednie wyrażenie woli stron względem ograniczenia analizowanego prawa wyboru może nastąpićzwłaszcza poprzez wyrażenie przez wydzierżawiającego zgody na poczynienie określonych nakładów ${ }^{14}$. Oceniając skutki zgody w tym zakresie należy zbadać wszelkie okoliczności sprawy ${ }^{15}$. Zgoda może być wyrażona w dowolny sposób ${ }^{16}$. Jak się wydaje, wskazana zgoda może skutkować jedynie ograniczeniem prawa wyboru w zakresie żądania restytucji (na co trafnie wskazał SN w glosowanym wyroku), natomiast a contrario nie będzie zasadniczo powodowała ograniczenia w zakresie wyboru pozostawienia nakładów za odpowiednią zapłatą ${ }^{17}$. Pośrednio wolę stron ograniczenia żądania restytucji może sugerować sytuacja, w której wydzierżawiający z własnej inicjatywy wniesie o dokonanie nakładów. Podobne skutki mogłaby powodować wiedza wydzierżawiającego odnośnie do czynionych przez dzierżawcę nakładów i (choćby milczące) akceptowanie przez niego takiego stanu rzeczy. Nie jest wykluczone, by niedopuszczalność żądania restytucji wynikała także $z$ innych ustaleń stron dotyczących (choćby pośrednio) przedmiotu dzierżawy ${ }^{18}$. Można tu wskazać np. dodatkowe porozumienie stron, niebędące częścią umowy dzierżawy, ale odnoszące się do dokonania ulepszeń (co miało miejsce w stanie faktycznym glosowanego wyroku).

Wskazane sytuacje w praktyce obrotu mogą pośrednio wskazywać na wolę stron co do niedopuszczalności przywrócenia stanu poprzedniego, jednak nie przesądzają w sposób automatyczny o jej rzeczywistej treści. W celu ustalenia, czy przysługujące wydzierżawiającemu prawo wyboru zostało ograniczone, należy wziąć pod

14 Zob. np. wyrok SN z dnia 11 października 2013 r., I CSK 86/13, LEX Nr 1523364.

15 Zob. np. wyrok SN z dnia 26 stycznia 2006 r., V CK 405/04, LEX $\mathrm{Nr} 195422$, dotyczący zgody na zmianę przeznaczenia nieruchomości.

${ }^{16}$ Zob. np. wyrok SN z dnia 15 września 2004 r., III CK 378/03, LEX $\mathrm{Nr}$ 269795, w którym wskazano, że zgoda na określoną działalność gospodarczą nie zawsze musi oznaczać jednocześnie zgodę na zmianę przedmiotu dzierżawy.

17 Zob. np. wyrok SN z dnia 9 listopada 2000 r., II CKN 339/00, op. cit.; G. Kozieł op. cit., s. 396.

18 Zob. wyrok SN z dnia 8 lipca 2010 r., II CSK 85/10, op. cit.; por. także K. Zaradkiewicz, op. cit., s. 562. 
uwagę i zbadać wszelkie okoliczności konkretnej sprawy. Dopiero w oparciu o nie można dokonać odpowiedniej wykładni i ocenić wolę stron względem ewentualnego ograniczenia prawa wyboru pomiędzy zatrzymaniem nakładów a restytucją (art. 60 k.c. i 65 k.c. ${ }^{19}$.Ważne jest, by rozstrzygnięcie pozwoliło na możliwie jak najpełniejsze zapewnienie ochrony prawnej oraz realizacji potrzeb i interesów obu stron umowy dzierżawy ${ }^{20}$. W świetle wskazanych uwag wydaje się, że teza analizowanego orzeczenia powinna zostać wzbogacona o stwierdzenie, że ewentualny zakaz restytucji będzie zależny także od woli stron. Nie uchybia to jednak ogólnej trafności glosowanego wyroku.

Nasuwa się pytanie o inne, poza wolą stron, okoliczności ograniczające przysługujące wydzierżawiającemu prawo wyboru między pozostawieniem nakładów a restytucją. Ograniczenia w tym zakresie mogą wynikać także $z$ przepisów ustawy normujących umowę dzierżawy. W szczególności będą to przepisy określające istotę, charakter (specyfikę) i wykonywanie umowy dzierżawy (zwłaszcza art. 694 k.c., 696 k.c. i 705 k.c.) ${ }^{21}$. Nie można więc, co do zasady, żądać usunięcia nakładów powstałych zgodnie $\mathrm{z}$ treścią ustawy (wskazanych przepisów), oczywiście o ile nie ma w tym zakresie odmiennej woli stron ${ }^{22}$. Wskazane przepisy ustawy wskazują na kilka okoliczności, które należy wziąć pod uwagę.

Zbadać należy zgodność dokonania określonych nakładów z zasadami prawidłowej gospodarki (art. 696 k.c. w zw. z art. 354 k.c.) ${ }^{23}$. Dzierżawca powinien dokonać inwestycji (w tym nakładów), które są uzasadnione ekonomicznie (gospodarczo) ${ }^{24}$. Przedmiot dzierżawy (w braku odmiennej umowy) powinien zostać zwrócony wydzierża-

19 Zob. wyrok SN z dnia 11.10.2013 r., I CSK 86/13, op. cit.

${ }^{20}$ Por. np. P. Machnikowski, op. cit., s. 211-216.

${ }^{21}$ Por. wyrok SN z dnia 26 stycznia 2006 r., V CK 405/04, op. cit.

22 Por. np. K. Zaradkiewicz, op. cit., s. 562.

${ }^{23}$ Por. wyrok SA w Warszawie $z$ dnia 21 maja 2013 r., VI ACa 1550/12, LEX Nr 1339416; H. Pietrzykowski, w: H. Ciepła, B. Czech, S. Dąbrowski, T. Domińczyk, H. Pietrzykowski, Z. Strus, M. Sychowicz, A. Wypiórkiewicz, Kodeks cywilny. Praktyczny komentarz z orzecznictwem, Warszawa 2005, s. 415.

${ }^{24}$ Por. wyrok SN z dnia 9 listopada 2000 r., II CKN 339/00, op. cit.; G. Kozieł, op. cit., s. 477 
wiającemu stosowanie do przepisów o wykonaniu dzierżawy, a więc wraz $z$ ulepszeniami wynikającymi $z$ prawidłowego gospodarowania (art. 705 k.c. i art. 696 k.c.) ${ }^{25}$. W przypadku braku odmiennej woli stron żądania przewrócenia stanu poprzedniego i usunięcia nakładów dokonanych zgodnie $\mathrm{z}$ zasadami prawidłowej gospodarki zasadniczo mogłoby zostać ocenione jako niedopuszczalne ${ }^{26}$. W tym zakresie należałoby, jak się zdaje, kwalifikować sformułowany w glosowanym wyroku zarzut nieekonomiczności żądania restytucji. Jednak ostateczna kwestia ograniczenia prawa wyboru zależy także od pozostałych okoliczności wskazanych w ustawie ${ }^{27}$.

Istotny jest również charakter ulepszeń (zmieniających lub niezmieniających przeznaczenie przedmiotu dzierżawy). Jak się wydaje, zgodność z zasadami prawidłowej gospodarki powinna polegać na dokonywaniu zwyczajnych (przyjętych w praktyce obrotu) ulepszeń nie zmieniających przedmiotu dzierżawy, które nie wymagają zgody wydzierżawiającego. Żądanie wydzierżawiającego, co do usunięcia wskazanych nakładów, mogłoby być uznane za niedopuszczalne ${ }^{28}$. Natomiast nakłady zmieniające przedmiot dzierżawy (zazwyczaj ulepszenia znacznej wartości), $z$ racji potrzeby ochrony interesu wydzierżawiającego ${ }^{29}$, mogłyby być dokonane jedynie za jego zgodą (art. 696 k.c. ${ }^{30}$; w doktrynie wskazuje się jednak na pewne wyjątki w tym zakresie ${ }^{31}$ ). W przypadku dokonania takich nakładów bez wymaganej zgody, ograniczenia prawa wyboru co do zasady nie powstałyby ${ }^{32}$.

Ponadto przy ocenie dopuszczalności ograniczenia prawa wyboru co do dalszego losu nakładów, winno się też rozważyć przydatność

${ }^{25}$ Nieco odmiennie niż przy umowie najmu - art. 675 § 1 k.c.

${ }^{26}$ Por. np. H. Pietrzykowski, op. cit., s. 424.

27 Por. P. Machnikowski, op. cit., s. 218 i 226.

${ }^{28}$ Por. np. W. Pańko, op. cit., s. 90-91; W. Czachórski, Zobowiązania, Warszawa 2007, s. 495.

${ }^{29}$ Zob. np. K. Zaradkiewicz, op. cit., s. 553.

30 Zob. np. wyrok SN z dnia 21 czerwca 2011 r., I CSK 598/10, LEX Nr 863906.

${ }^{31}$ Zob. np. wyrok SN z dnia 15 września 2004 r., III CK 378/03, op. cit.; G. Kozieł, op. cit., s. 477-478 i 497.

${ }^{32}$ Zob. np. J. Nadler, w: Kodeks cywilny. Komentarz, red. E. Gniewek, Warszawa 2011, s. 1194. 
i rzeczywistą wartość ulepszeń dla wydzierżawiającego, wolę stron, ustalone zwyczaje, a także wszelkie inne okoliczności konkretnej sprawy $^{33}$.

Ograniczenia przysługującego wydzierżawiającemu prawa wyboru mogą nastąpić także $z$ uwagi na inne przepisy ustawowe (poza szczegółowymi przepisami normującymi umowę dzierżawy art. 693 k.c. -709 k.c.). Mogłoby to mieć miejsce zwłaszcza z uwagi na naruszenie natury dzierżawy (oprócz wskazanych wcześniej sytuacji), zasad współżycia społecznego lub przepisów prawa (art. 353 ${ }^{1}$ oraz 58 k.c. $)^{34}$. Dopuszczalne byłoby również skorzystanie $z$ konstrukcji nadużycia prawa podmiotowego w celu ograniczenia żądania restytucji przedmiotu dzierżawy, jeżeli prowadziłoby ono do skutków niemożliwych do zaakceptowania $z$ aksjologicznego punktu widzenia (art. 5 k.c.). Z uwagi na wyjątkowy charakter tego przepisu należałoby go zastosować dopiero w ostateczności, jeśli ograniczenie analizowanego prawa wyboru nie byłoby możliwe w oparciu o wolę stron lub inne przepisy ustawowe (zwłaszcza normujące umowę dzierżawy) ${ }^{35}$. Takie rozstrzygnięcie, przyjęte przez Sąd Najwyższy w glosowanym wyroku, w pełni zasługuje na aprobatę.

33 Zob. np. wyrok SN z dnia 15 września 2004 r., III CK 378/03, op. cit.; wyrok SA w Szczecinie z dnia 30 stycznia 2014 r., I ACa 602/13, op. cit.; W. Czachórski, op. cit., s. 495.

34 Por. np. wyrok Sądu Najwyższego z dnia 27 października 2004 r., IV CK 122/04, LEX Nr 303365.

35 Zob. np.: wyrok SN z dnia 7 września 2000 r., I CKN 265/00, LEX Nr 536120; wyrok SN z dnia 25 sierpnia 2011 r., II CSK 640/10, LEX Nr 964496; wyrok SN z dnia 9 grudnia 2009 r., IV CSK 290/09, LEX Nr 560607; M. Pyziak-Szafnicka, w: Kodeks cywilny część ogólna, red. M. Pyziak-Szafnikca, P. Księżak, Warszawa 2014, s. 109 i 115. 